\title{
QUEEN'S
UNIVERSITY
BELFAST
}

\section{BRCA1, FANCD2 and Chk1 are potential molecular targets for the modulation of a radiation-induced DNA damage response in bystander cells}

Burdak-Rothkamm, S., Rothkamm, K., McClelland, K., Al Rashid, S. T., \& Prise, K. M. (2015). BRCA1, FANCD2 and Chk1 are potential molecular targets for the modulation of a radiation-induced DNA damage response in bystander cells. Cancer Letters, 356(2 Pt B), 454-61. https://doi.org/10.1016/j.canlet.2014.09.043

\section{Published in:}

Cancer Letters

\section{Document Version:}

Peer reviewed version

Queen's University Belfast - Research Portal:

Link to publication record in Queen's University Belfast Research Portal

\section{Publisher rights}

(C) 2014 Elsevier Ireland Ltd.

This manuscript version is made available under the CC-BY-NC-ND 4.0 license (http://creativecommons.org/licenses/by-nc-nd/4.0/), which permits distribution and reproduction for non-commercial purposes, provided the author and source are cited.

\section{General rights}

Copyright for the publications made accessible via the Queen's University Belfast Research Portal is retained by the author(s) and / or other copyright owners and it is a condition of accessing these publications that users recognise and abide by the legal requirements associated with these rights.

Take down policy

The Research Portal is Queen's institutional repository that provides access to Queen's research output. Every effort has been made to ensure that content in the Research Portal does not infringe any person's rights, or applicable UK laws. If you discover content in the

Research Portal that you believe breaches copyright or violates any law, please contact openaccess@qub.ac.uk. 


\section{BRCA1, FANCD2 and Chk1 are potential molecular targets for the modulation of a radiation-induced DNA damage response in bystander cells}

Susanne Burdak-Rothkamm ${ }^{1,2, ~}{ }^{\star}$, Kai Rothkamm ${ }^{3}$, Keeva McClelland ${ }^{1}$, Shahnaz T. Al Rashid ${ }^{1}$ and Kevin M. Prise ${ }^{1}$

${ }^{1}$ Centre for Cancer Research and Cell Biology, Queen's University Belfast, 97 Lisburn Road, Belfast, BT9 7BL, UK

${ }^{2}$ current address: Oxford University Hospitals, Headley Way, Headington, Oxford OX3 9DU, UK

${ }^{3}$ Public Health England, Centre for Radiation, Chemical and Environmental Hazards, Chilton/Didcot OX11 ORQ, UK

*corresponding author:

e-mail: s.burdakrothkamm@yahoo.co.uk

Key words: Radiation-induced bystander effect, ionising radiation, DNA damage response, BRCA, Fanconi anaemia 


\section{Abstract}

Radiotherapy is an important treatment option for many human cancers. Current research is investigating the use of molecular targeted drugs in order to improve responses to radiotherapy in various cancers. The cellular response to irradiation is driven by both direct DNA damage in the targeted cell and intercellular signalling leading to a broad range of bystander effects.

This study aims to elucidate radiation-induced DNA damage response signalling in bystander cells and to identify potential molecular targets to modulate the radiation induced bystander response in a therapeutic setting.

Stalled replication forks in T98G bystander cells were visualised via bromodeoxyuridine (BrdU) nuclear foci detection at sites of single stranded DNA. $\mathrm{yH} 2 \mathrm{AX}$ co-localised with these BrdU foci. BRCA1 and FANCD2 foci formed in T98G bystander cells. Using ATR mutant F02-98 hTERT and ATM deficient GM05849 fibroblasts it could be shown that ATR but not ATM was required for the recruitment of FANCD2 to sites of replication associated DNA damage in bystander cells whereas BRCA1 bystander foci were ATM-dependent. PhosphoChk1 foci formation was observed in T98G bystander cells. Clonogenic survival assays showed moderate radiosensitisation of directly irradiated cells by the Chk1 inhibitor UCN-01 but increased radioresistance of bystander cells. This study identifies BRCA1, FANCD2 and Chk1 as potential targets for the modulation of radiation response in bystander cells. It adds to our understanding of the key molecular events propagating out-of-field effects of radiation and 
provides a rationale for the development of novel molecular targeted drugs for radiotherapy optimisation. 


\section{Introduction}

Radiotherapy is a main treatment option for cancer patients, often combined with surgery and chemotherapy. Direct effects of radiation and their modulation for the benefit of treatment outcome (e.g. fractionation) have been extensively studied and this has led to much improved survival rates. In the last decade, radiationinduced non-targeted bystander responses have increasingly been a focus of research, and may have significant potential for radiotherapy treatment optimisation [1-3]. Radiation induced non-targeted effects have been reported for a range of biological endpoints [4-9] including the induction of the DNA damage marker $\mathrm{yH} 2 \mathrm{AX}[10-15]$.

Most recently, ataxia-telangiectasia and Rad3-related (ATR) has been identified as a central player within the bystander signalling cascade that is responsible for H2AX phosphorylation. The ataxia-telangiectasia mutated (ATM) protein was found to be activated downstream of ATR [16] and ATR-mediated, S-phase dependent $\mathrm{yH} 2 \mathrm{AX}$ and 53BP1 foci induction was observed [11]. These observations support the hypothesis of an accumulation of replication-associated DNA damage in bystander cells. DNA replication fork stalling can be caused by DNA damage through reactive oxygen or nitrogen species which are thought to play a central role in DNA damage induction in bystander cells. ATR is involved in the recognition of stalled replication forks, failure to stabilise them results in their collapse and ultimately in genetic instability (reviewed in [17]). The report of S-phase specific DNA damage recognised through an ATR and H2AX dependent mechanism in bystander cells strongly suggests the subsequent activation of the 
Fanconi Anaemia (FA)/BRCA network which is a key pathway in the homologous recombination-dependent resolution of stalled replication and regulation of the intra-S-phase cell cycle checkpoint [18-20]. Phosphorylation of FANCD2 by either ATR or ATM is required for the induction of an intra-S-phase arrest. FA core proteins, ATR and RPA1 [21] are required for the ubiquitination of the FANCD2 protein in S-phase, a modification that is prerequisite for the accumulation at sites of DNA damage to form microscopically visible nuclear foci which associate with BRCA1, BRCA2 and RAD51. $\mathrm{YH} 2 \mathrm{AX}$ in connection with BRCA1 recruits FANCD2 to chromatin at stalled replication forks [22] suggesting that $\mathrm{H} 2 \mathrm{AX}$ is functionally linked to the FA/BRCA pathway to resolve stalled replication forks and prevent chromosome instability.

The cell cycle checkpoint kinase Chk1 is regulated by ATR and is involved in the activation of the FA/BRCA pathway through phosphorylation of FANCE [23]. The G(2)/M [24] and S-phase DNA damage checkpoints require Chk1 activation [25]. The FA/BRCA DNA repair pathway is frequently affected in breast cancer where BRCA1 or BRCA2 mutations can be found in approximately $10 \%$ of cases. Epigenetic silencing of BRCA1 occurs in $13 \%$ of breast cancers, $6 \%$ of cervical cancers and $4 \%$ of non-small-cell lung cancers. FANCF methylation is found in $30 \%$ of cervical cancer, $14 \%$ of squamous cell head and neck cancers, $6.7 \%$ of germ cell tumours of testis, and $15 \%$ of non-small-cell lung cancers [26]. This study investigates the hypothesis of an activation of the FA/BRCA network in the radiation-induced bystander response at sites of stalled replication promoting both DNA repair by homologous recombination and intra-S-phase 
checkpoint activation in bystander cells which is supported by our previous report of an S-phase restricted, ATR dependent formation of $\mathrm{\gamma H} 2 \mathrm{AX}$ and 53BP1 foci in bystander cells $[11,16]$.

\section{Materials and Methods}

\subsection{Cell Culture and irradiations}

T98G glioma cells and GM05849 ATM deficient fibroblasts were cultured in RPMI 1640 medium (Cambrex, Verviers, Belgium) supplemented with $10 \%$ FBS (PAA, Pasching, Austria), $2 \mathrm{mM} \mathrm{L-glutamine,} 100$ units $/ \mathrm{ml}$ penicillin and $100 \mu \mathrm{g} / \mathrm{ml}$ streptomycin (all Cambrex, Verviers, Belgium). ATR mutated Seckel cells (F02/98 hTERT) and 48BR hTERT fibroblasts were cultured in MEM medium supplemented with $15 \%$ FBS (PAA, Pasching, Austria), 2 mM L-glutamine, 100 units $/ \mathrm{ml}$ penicillin, $100 \mu \mathrm{g} / \mathrm{ml}$ streptomycin (all Cambrex, Verviers, Belgium) and $0.4 \mu \mathrm{g} / \mathrm{ml}$ puromycin (Sigma, Poole, UK). All cells were incubated at $37^{\circ} \mathrm{C}, 5 \%$ $\mathrm{CO}_{2}$. For all experiments sub-confluent cell cultures were used.

For medium transfer experiments cells were seeded on $22 \times 22 \mathrm{~mm}^{2}$ coverslips placed in 6-well tissue culture dishes and treated with filtered medium obtained from T98G cells, which had been irradiated with 2 Gy of X-rays (Pantak, X-ray set, $240 \mathrm{KV}$ ) at $37^{\circ} \mathrm{C}$. Following $30 \mathrm{~min}$ incubation the medium was taken off and filtered using a $0.45 \mu \mathrm{m}$ syringe filter. The recipient cells were incubated with the conditioned medium at $37^{\circ} \mathrm{C}, 5 \% \mathrm{CO}_{2}$ for $24 \mathrm{~h}$ followed by fixation and immunocytochemistry. Sham-treated cells were used as controls. For direct irradiations, cells were seeded on $22 \times 22 \mathrm{~mm}^{2}$ coverslips placed in 6-well tissue 
culture dishes and irradiated in cell culture medium at $37^{\circ} \mathrm{C}$ with 1 and/or 5 Gy of X-rays (Pantak, X-ray set, 240KV) to induce similar BRCA1 and FANCD2 foci yields as those observed in bystander cells. Cells were incubated at $37^{\circ} \mathrm{C}, 5 \%$ $\mathrm{CO}_{2}$ for $4 \mathrm{~h}$ after direct radiation before fixation and immunocytochemistry.Caffeine (Sigma, Poole, UK) was used at a concentration of $1 \mathrm{mM}$ which has been demonstrated and is being widely used to inhibit ATR and ATM [27-29]. The specific ATM inhibitor (ATMi) Ku55933 was used at a concentration of $10 \mu \mathrm{M}$.

\subsection{Bromodeoxyuridine labelling of DNA}

In order to visualise stalled replication forks in bystander cells, sub-confluent T98G cells were labelled with bromodeoxyuridine $(\mathrm{BrdU})$ for $21 \mathrm{~h}$, treated with conditioned medium from irradiated cells for $3 \mathrm{~h}$, then stained for BrdU nuclear

foci (rat anti-BrdU, Cancer Research UK) applying a protocol without prior DNA denaturation [30] which relies on the recognition of single stranded, BrdUlabelled DNA at sites of replication fork stalling. For $\mathrm{yH} 2 \mathrm{AX}$ co-localisation with BrdU foci, the BrdU staining protocol was combined with the $\mathrm{yH} 2 \mathrm{AX}$ staining protocol described below.

A routine BrdU pulse labelling method was used to determine the fraction of actively replicating cells in control and bystander cell cultures treated with conditioned medium from 2 Gy-irradiated cells. $20 \mu \mathrm{M}$ BrdU was added for 15 min prior to ethanol fixation at $-20^{\circ} \mathrm{C}$ overnight. Following treatment with $2 \mathrm{M}$ hydrochloric acid for $15 \mathrm{~min}$ at room temperature and neutralisation with $0.1 \mathrm{M}$ 
sodium borate buffer, samples were washed in $0.5 \%$ Triton X100 in PBS, blocked in 3\% foetal calf serum in PBS for 30 min, incubated with anti-BrdU antibody, washed in $0.1 \%$ Triton X 100 in PBS, incubated in Alexa Fluor 488conjugated secondary antibody (Molecular Probes, Leiden, The Netherlands) for 30 min, washed in PBS and resuspended in propidium iodide/RNAse in PBS. Flow cytometry was performed using a Becton Dickinson FACScan and the fraction of BrdU-positive and -negative cells was determined using CellQuest software (Becton Dickinson).

\subsection{Immunocytochemistry}

For immunocytochemistry, cells grown on coverslips were fixed for 15 min with 4 $\%$ paraformaldehyde, permeabilized with $0.5 \%$ Triton-X 100 (both Sigma, Poole, UK) and blocked with $3 \%$ FBS (PAA, Pasching, Austria) in PBS for 30 min at room temperature. Incubation with a primary antibody specific for H2AX p139S (Upstate, Chandlers Ford, UK), 53BP1 (Novus Biologicals, Littleton, CO, USA), BRCA1 (Oncogene, Cambridge, MA, USA), phospho-Chk1 (p348S; (Santa Cruz Biotechnology), BRCA1 (Oncogene Research Products; Ab-1) or FANCD2 (Santa Cruz Biotechnology; sc28194) for $1 \mathrm{~h}$ at room temperature was followed by three washes of 10 min each in PBS/3\% FBS and incubation with a matching Alexa Fluor 488 or 568 conjugated secondary antibody (Molecular Probes, Leiden, The Netherlands). DAPI-stained coverslips were mounted onto glass slides using Vectashield mounting medium (Vector Laboratories, Burlingame, $\mathrm{CA})$ and the edges were sealed with clear nail varnish. A fluorescence 
microscope was used for imaging and analysis (Zeiss, Welwyn Garden City, UK). Foci were scored by eye in all cells visible in each field of view. Average foci per cell and distribution of foci levels in the analysed cell population were calculated using Microsoft Excel. For the calculation of induced foci per cell, background foci numbers in untreated control cells were subtracted.

\subsection{Western Blot}

Cells were lysed in buffer ( $1 \%$ Igepal, $0.1 \%$ SDS, $0.05 \%$ sodium deoxycholate, 1 protease inhibitor tablet and 1 PhosSTOP tablet (Roche, UK)) and protein concentration determined using the BCA assay (Pierce, UK) according to manufacturer's instructions. Samples were then subject to SDS-PAGE electrophoresis using the XCell SureLock Mini-Cell system (Invitrogen, UK), transferred onto nitrocellulous membranes (Millipore, UK), blocked for $1 \mathrm{~h}$ in $3 \%$ skim milk blocking solution and probed accordingly. Antibody binding was detected using Supersignal West Pico or Femto Chemiluminescent substrate (Pierce, UK) according to manufacturer's instructions. Antibodies: anti- phospho Chk1 S345 diluted 1:500 (Cell Signalling, UK), anti-BRCA1 diluted 1:500 (Santa Cruz) and anti- $\beta$ Actin diluted 1:2500 (Sigma, UK).

\subsection{Clonogenic Assay}

500 cells were seeded in each T25 tissue culture flask containing filtered medium derived from irradiated (2 Gy, X-rays) or sham-irradiated cells, and incubated for $10-14$ days at $37^{\circ} \mathrm{C}, 5 \% \mathrm{CO}_{2}$. For experiments involving direct irradiation, 
individual radiation doses were 0, 1, 2 and 5 Gy, with 500, 1000, 2000 and 5000 cells seeded per flask, respectively. Flasks were stained with crystal violet staining solution, and individual colonies were counted. Average surviving fractions and standard errors (SEM) of 2 - 4 independent experiments performed in triplicates were calculated. The Chk1 inhibitor UCN-01 (7hydroxystauosporine) $[31,32]$ was added to the culture medium at a final concentration of $10 \mathrm{nM} 15$ min prior to direct irradiation, or was added into the conditioned medium prior to transfer to recipient cells for bystander experiments.

\subsection{Data analysis}

Average foci numbers per cell, average survival fractions and standard errors were calculated using Microsoft Excel for Windows 2003 or 2010. The significance of reported findings was tested with a t-test comparing treated samples with their sham treated controls. Significance levels are provided in the text.

Colocalisation analysis of $\mathrm{BrdU}$ and $\mathrm{yH} 2 \mathrm{AX}$ foci was analysed with Image software using Pearson correlation coefficients [33] and Costes' spatial statistics method [34].

\section{Results}

\section{1 Stalled replication forks in bystander cells}

On the basis of published cell cycle distribution data of bystander cells and the Sphase specificity of bystander foci formation $[11,16]$ we postulated that $\mathrm{\gamma H} 2 \mathrm{AX}$ 
and 53BP1 foci form at sites of stalled replication forks during $S$ phase in bystander cells. To test this hypothesis, T98G glioma cells were cultured in BrdUcontaining medium for $21 \mathrm{~h}$ resulting in overall labelling of DNA during one cycle of DNA replication followed by incubation with filtered conditioned medium derived from irradiated T98G cells for $3 \mathrm{~h}$. Stalled replication forks that expose short patches of single stranded, BrdU-labelled DNA were detected by anti-BrdU immunofluorescence microscopy and appeared as nuclear foci. Treatment with $20 \mu \mathrm{M}$ hydroxyurea for $3 \mathrm{~h}$ was included as a positive control. Immunofluorescence co-staining with a $\mathrm{yH} 2 \mathrm{AX}$ specific antibody confirmed colocalisation of $\mathrm{BrdU}$ foci at sites of stalled replication with $\mathrm{yH} 2 \mathrm{AX}$ foci in bystander cells (Figure 1A), with a mean Pearson correlation coefficient of 0.85 and significant correlation in all 20 analysed cells, according to Costes' spatial statistics method. Additional representative images are included in Supplementary Figure S1. Formation of both BrdU foci and co-localising $\mathrm{yH} 2 \mathrm{AX}$ foci were inhibited by the ROS scavenger DMSO and by Filipin, a disruptor of lipid rafts in the cell membrane and inhibitor of membrane signalling (Figure 1B). Additional representative images are included in Supplementary Figure S1. These findings confirm a role for ROS and membrane signalling in the induction of oxidative DNA damage in non-targeted cells.

Replication stalling at sites of oxidative DNA damage in non-targeted cells can be expected to activate the intra-S phase checkpoint and slow down replication progression, resulting in a larger $\mathrm{S}$ phase fraction in bystander cells compared to untreated cells. To test this hypothesis, control and bystander cell cultures were 
pulse-labelled with BrdU and the fraction of BrdU-positive cells determined using flow cytometry. Figure 1C shows that the percentage of BrdU-positive cells increases significantly in T98G $(p=0.01)$ and 48BR hTERT bystander cells $(p=0.05)$, compared to controls. In contrast, no significant increase was detected in ATR-deficient FO2/98 hTERT and ATM-deficient GM05849 human fibroblasts. Figure 1D shows the persistent increase of $\mathrm{yH} 2 \mathrm{AX}$ foci in cultures of bystander T98G cells over a period of $24 \mathrm{~h}$.

\subsection{FANCD2 and BRCA1 foci induction in bystander cells}

Immunostaining for BRCA1 and FANCD2 was performed to determine the involvement of the BRCA/FA network in bystander signalling.

Directly irradiated T98G cells received an X-ray dose of 5 Gy and were subsequently stained for BRCA1 nuclear foci after $4 \mathrm{~h}$ incubation time. For the detection of BRCA1 bystander foci, cells were treated for $24 \mathrm{~h}$ with filtered medium derived from T98G cells irradiated with 2 Gy of X-rays (Figure 2A; see Supplementary Figure S2 for additional representative immunofluorescence microscopy images). Bystander cells showed a significant induction of BRCA1 foci above background level ( $p=0.02$, Figure $2 \mathrm{C}$ ) although the fraction of cells without any foci remained at control level (Figure 2B). This finding is consistent with the S-phase dependence of bystander foci formation, as cells without foci are known to be mostly in the $\mathrm{G} 1$ phase of the cell cycle $[11,16]$. In contrast, high numbers of nuclear BRCA1 foci were induced in all directly irradiated cells, 
without any sign of a 'resistent' subpopulation (Figure 2B). In this context it should be noted that the T98G control cultures analysed here contained $42 \pm 4 \%$ S phase cells (BrdU-positive following pulse-labelling for $15 \mathrm{~min}$ ), rising to $53 \pm 4$ $\%$ in bystander cells, measured using flow cytometry (raw data not shown). Western blot analysis of lysates from T98G cells treated with conditioned medium for 30 min or $4 \mathrm{~h}$ demonstrated a 2-3-fold increase of BRCA1 protein compared with control cells ( $p=0.04$, Figure 2D,E). Cells irradiated directly with 2 Gy were included as a positive control in the experiment. Induction of FANCD2 foci (Figure 3A \& B, see also Supplementary Figure S2 for additional representative immunofluorescence microscopy images) was detected both in directly irradiated and bystander cells, but only in a fraction of the cells (Figure 3B), which are most likely S-phase cells as FANCD2 nuclear foci are known to accumulate at stalled replication forks [22]. Comparison of induced BRCA1 and FANCD2 foci in directly irradiated and bystander cells with $\mathrm{yH} 2 \mathrm{AX}$ foci induction (Figure $3 \mathrm{C}$ ) revealed a similar pattern of BRCA1 and $\mathrm{yH} 2 \mathrm{AX}$ foci induction in cells directly irradiated with 5 Gy with an average of 23 and 25 induced foci per cell at $4 \mathrm{~h}$ after irradiation, whereas FANCD2 foci induction was on average 3.9 foci per cell. In bystander cells, BRCA1, FANCD2 and $\mathrm{yH} 2 \mathrm{AX}$ foci induction was at a similar level with 2.4, 2.1 and 3.6 induced foci per cell after $24 \mathrm{~h}$ of incubation with conditioned medium. Supplementary figure 4 (S4) shows the average number of foci per cell in focicontaining cells only versus the whole cell population for p-Chk1, FANCD2, BRCA1 and $\mathrm{yH} 2 \mathrm{AX}$. These observations, taken together with the evident S- 
phase dependency of bystander foci induction which has previously been addressed in greater detail $[11,16]$, support the hypothesis of an S-phase dependent bystander DNA damage response involving $\mathrm{YH} 2 \mathrm{AX}, \mathrm{BRCA} 1$ and FANCD2.

\subsection{BRCA1 and FANCD2 foci in ATR/ATM mutant cell lines, ATM- inhibited and caffeine treated cells}

The reduction in clonogenic survival of bystander cells depends on ATR function and subsequent ATM activation [16] whereas bystander $\mathrm{yH} 2 \mathrm{AX}$ foci induction requires ATR but not ATM [11]. To determine whether ATR and/or ATM are involved in the activation of the BRCA/FA network in bystander cells, ATR mutant F02-98 hTERT cells, ATM deficient GM05849 cells and ATMi or caffeine treated T98G cells were treated with conditioned medium derived from irradiated T98G cells and analysed for the induction of BRCA1 and FANCD2 foci (Figure 4A and 4B) in comparison to T98G cells.

FANCD2 bystander foci were detected in T98G $(p<0.01)$, ATMi-treated and ATMdeficient GM05849 cells $(p<0.01)$ but not in ATR mutated F02-98 hTERT cells and T98G cells treated with the ATR/ATM inhibitor caffeine. This indicates that ATR, but not ATM, is required for the recruitment of FANCD2 to sites of replication associated DNA damage in bystander cells.

BRCA1 bystander foci were induced in T98G cells $(p=0.02)$ but not in ATR mutated F02-98 hTERT, ATM deficient GM05849 or ATMi or caffeine treated T98G cells. These results suggest an essential role for ATM in the formation of 
nuclear BRCA1 foci in bystander cells. As shown previously [16], the activation of ATM in bystander cells depends on functional ATR. Therefore, the inactivation of either ATR or ATM prevents the formation of BRCA1 nuclear foci in bystander cells.

\subsection{Phosphorylation of Chk1 in bystander cells and inhibition of a clonogenic bystander effect by the Chk1 inhibitor UCN-01}

Chk1 is a main downstream target of ATR and is involved in the activation of the BRCA/FA pathway [23]. Therefore, we tested the hypothesis of bystander Chk1 activation which could provide a functional link between activation of ATR and BRCA/FA in bystander cells. Cells were treated for $24 \mathrm{~h}$ with filtered medium derived from 2 Gy X-irradiated T98G cells and immunostained for phospho-Chk1 (p348S). Significantly increased phospho-Chk-1 foci formation was observed in T98G bystander cells $(p<0.01$, Figure 5A,B; see Supplementary Figure S3 for additional representative immunofluorescence microscopy images). This was confirmed by Western blot analysis of protein lysate received from T98G cells treated for 30 min with filtered medium from irradiated cells $(p=0.07)$. Lysate from cells irradiated directly with 5 Gy was included in this experiment as a positive control (Figure 5C,D).

In order to test the functional importance of Chk1 in bystander responses, T98G cells were treated with the Chk1 inhibitor UCN-01 one hour prior to radiation and during subsequent incubation for colony formation in a clonogenic assay. A concentration of $10 \mathrm{nM}$ resulted in a moderate radiosensitisation of T98G cells $(p<0.05$, Figure $6 A)$. Bystander cells were treated with medium derived from 
T98G cells treated with $10 \mathrm{nM} \mathrm{UCN-01}$ and irradiated with 2 Gy. Whereas shamtreated controls showed a significant reduction of the clonogenic survival of bystander cells $(p<0.05), U C N-01$-treated cultures were protected and showed only a minor non-significant bystander effect (Figure 6B). In T98G cells, higher doses of UCN-01 were toxic and could therefore not be tested for a further increase of the effect.

\section{Discussion}

This study aims to further clarify the DNA damage response network in bystander cells and to identify potential targets for novel molecular inhibitors. We have previously shown the S-phase restricted induction of $\mathrm{yH} 2 \mathrm{AX}$ nuclear foci in an ATR dependent manner and the activation of ATM downstream of ATR in bystander cells $[11,16]$. Over the past few years, a novel FA/BRCA DNA damage response pathway has been uncovered which is a key pathway in the resolution of stalled replication and regulation of the intra-S-phase cell cycle checkpoint [20]. Functional loss of members of this pathway is linked to genomic instability [35].

The DNA damage response during DNA replication in S-phase includes an ATM / ATR mediated intra-S-phase checkpoint which suppresses DNA replication in response to DNA damage and also involves Chk1. Stabilisation and restarting of stalled replication forks involves proteins related to homologous recombination (HR) like Rad51 and various other proteins including RPA, ATR, 53BP1, BLM, $\mathrm{YH} 2 \mathrm{AX}$ and BRCA1 (reviewed in [17]). 
This study demonstrates the accumulation of stalled replication forks in bystander cells and their co-localisation with $\mathrm{yH} 2 \mathrm{AX}$ foci. As bystander cells show an ATR- and ATM-dependent intra-S-phase arrest, it is important to note that bystander foci induction in S-phase cells may cause a further increase in overall foci numbers through subsequent accumulation of cells in S phase. However, full characterisation of such a response would require complex, longterm time-lapse microscopy studies of foci formation in a bystander cell population.

Bystander cells show the induction of FANCD2 and BRCA1 nuclear foci which are central proteins of the FA/BRCA DNA damage response network. Whilst the induction of bystander FANCD2 foci is ATR dependent but independent of ATM, the induction of BRCA1 bystander foci requires both ATR and ATM function. In this context, the question arises whether further molecules are involved as intermediaries in this pathway activation, given the complexity of the FA DNA repair network that has been uncovered in recent years [18-23,56]. Future studies are required as this is beyond the scope of this current study. While this study does not directly demonstrate that FANCD2 bystander foci form in S-phase cells, there is a strong line of argumentation from our previously published bystander studies and this current study to support this interpretation: (i) It has been thoroughly demonstrated that $\mathrm{yH} 2 \mathrm{AX}$ foci are formed in S-phase cells via co-staining with CENP-F [11]; (ii) $\mathrm{YH} 2 \mathrm{AX}$ foci co-localise with BrdU foci, highlighting replication fork stalling; (iii) $\mathrm{YH} 2 \mathrm{AX}$ foci co-localise with $\mathrm{BRCA} 1, \mathrm{ATR}$ 
and ATM foci in bystander cells [16]; (iv) FANCD2 and $\mathrm{YH} 2 \mathrm{AX}$ foci co-localise in bystander cells (Supplementary Figure 5).

Interestingly, a recent study by Redon et al. suggests that malignant tumours induce a DNA damage response in proliferating distant tissue similar to the DNA damage response in the proposed bystander model $[36,37]$.

A previous study has demonstrated that the bystander effect observed in a coculture of targeted and non-targeted cells persists for at least $24 \mathrm{~h}$ following irradiation, using $\mathrm{YH} 2 \mathrm{AX}$ foci induction in T98G cells as experimental system (Figure 3 in [11]). In this study, a persistent increase of $\mathrm{yH} 2 \mathrm{AX}$ bystander foci for at least $24 \mathrm{~h}$ has also been confirmed for medium transfer experiments. This observation is supported by two independent reports by Facoetti et al. [38] and Zhang et al. [39] who also report a persistent bystander response in medium transfer experiments involving different endpoints than gamma-H2AX foci formation. However, no data have been obtained yet on the dose dependence of bystander foci induction. Yet, based on the general observation of doseindependent bystander effects (e.g. Figure 4 from [4]) one would not expect to see a difference for conditioned medium obtained from cells exposed to different doses.

The nature of the signal triggering a DNA damage response in non-targeted cells is still not entirely clear. Subnuclear foci of $\mathrm{yH} 2 \mathrm{AX}$ and 53BP1 are well known to be associated with DNA double-strand breaks but their formation in bystander cells likely reflects only a secondary event triggered by stalled replication forks 
rather than prompt "two-ended" DSBs. These stalled replication forks have been postulated to be a consequence of an accumulation of ROS leading to DNA damage, including base damage which accumulates in S-phase leading to replication fork stalling and secondary production of DSBs and chromosomal aberrations [40]. Increasing ROS levels following treatment with conditioned medium from irradiated cells have previously been reported [41]. The results presented suggest that bystander signals act in a similar manner as inter-strand crosslinks [42], ultraviolet light-induced damage [43], and human papillomavirus type 16 E7 oncoprotein-mediated replication stress [44]. All these factors activate the FA/BRCA pathway and may not directly induce DSBs but rather lead to secondary DNA breaks that form during replication, for example when the replication fork encounters an unrepaired single-strand break. Such "one-ended" breaks are normally repaired via homologous recombination-dependent processes. The previous observation that sister chromatid exchanges are induced in bystander cells [45] in a homologous recombination-dependent manner [46] is consistent with this concept.

A central role for Chk1 in the activation of the BRCA/FA network has been reported previously [23]. Our results show an activation of Chk1 in the radiationinduced bystander DNA damage response and suggest the suitability of Chk1 as a further potential target to differentially modulate radiation effects on directly irradiated and non-targeted bystander cells. In a similar manner to the Chk1 response reported here, where the Chk1 inhibitor UCN-1 acted as a radiosensitizer in directly radiated cells but increased survival in bystander cells 
(Figure 6), ATR and ATM inhibitors have previously been demonstrated to differentially modulate targeted and bystander responses for the endpoint of clonogenic cell survival [16]. It is thought that inhibition of the repair proteins involved in the bystander response may increase the survival of damaged cells which may otherwise have undergone cell cycle arrest or apoptosis. However, this hypothesis has not been tested yet and will be the subject of future studies. The FA/BRCA pathway is affected in many human tumours including bladder [47], breast [48] and cervical [49] cancer either through gene mutations or epigenetic changes, and inherited mutation in either BRCA1 or BRCA2 causes a hereditary breast and ovarian cancer syndrome. Many of these cancers are treated with radiotherapy. Investigating the role of this pathway in the response to radiation-induced DNA damage is therefore important for treatment optimisation. Especially pathways targeted by novel molecular inhibitors (e.g. PARP inhibitors in BRCA mutated tumours [50], ATM inhibitors or Chk1 inhibitors) with the potential for combined radiotherapy [51] need to be investigated regarding their effects on directly irradiated and bystander cells. Furthermore, increased clinical as well as cellular radiosensitivity has been reported for some but not all patients with inherited defects in the FA/BRCA pathway [52-59], adding to the complexity of radiotherapy treatment optimisation.

Limiting the radiation induced genomic damage of normal cells, which may further lead to cancer formation is key in the field of radiation protection. Furthermore, radiation induced bystander cells are at risk for late genomic instability, which is associated with many cancers. Further studies on genomic 
instability in bystander cells will be needed to understand the possible mechanisms of secondary cancers after radiation exposure.

\section{Acknowledgments}

Grant support was received from Cancer Research UK (C1513/A7047) and from Breast Cancer Campaign (2009MayPR03). 


\section{Figure Legends}

Figure 1: Immunofluorescence microscopic visualisation of stalled replication forks in bystander T98G cells. (A) Co-localisation of BrdU foci with $\mathrm{yH} 2 \mathrm{AX}$ nuclear foci at sites of stalled replication in bystander cells and cells treated with $20 \mu M$ hydroxyurea; (B) Inhibition of BrdU and $y H 2 A X$ nuclear foci in bystander cells by Filipin and DMSO. (C) Increase in the fraction of BrdU-positive cells detected by flow cytometry following pulse-labelling of bystander and corresponding control cultures. Bars show average values from 3 independent experiments for each cell line. Error bars show the associated standard errors. (D) Persistent increase of bystander gamma-H2AX foci numbers in T98G cell cultures treated for $0.5,4$ or $24 \mathrm{~h}$ with conditioned medium. Bars show average values from 2-6 independent experiments for each time point. Error bars show the associated standard errors.

Figure 2: BRCA1 induction in directly irradiated and bystander T98G cells. (A) Anti-BRCA1 immunofluorescence microscopic images of control, bystander and directly irradiated cells. Nuclei were counterstained with DAPI. (B) Distribution and $(C)$ average values of BRCA1 foci in control, bystander and directly irradiated cells. Foci data were collected from a total of 204 control and 204 bystander cells in four independent experiments and 531 Gy and 395 Gyirradiated cells in one experiment. (D) Western blot analysis for BRCA1 and $\beta$ actin expression. Densitometric intensity profiles are shown for control (thin line), 
2 Gy-irradiated (dashed line) and bystander samples (thick line). Densitometry readings are quantified on a linear scale. (E) Fold change relative to unirradiated controls in BRCA1 expression levels of irradiated and bystander samples following normalisation to $\beta$-actin levels. Error bars show the standard errors.

Figure 3: (A\&B) Induction of FANCD2 foci in directly 5 Gy-irradiated and bystander T98G cells. The diagram shows the distribution of foci. Foci data were collected from a total of 78 control and 98 bystander cells in two independent experiments and 685 Gy-irradiated cells in one experiment. Error bars show the standard errors (C) Bystander and 5 Gy-induced yH2AX, FANCD2 and BRCA1 foci in T98G cells. Foci counts in control samples were subtracted. Bars represent average induced foci per cell; error bars show SEM from 2-5 experiments.

Figure 4: Bystander BRCA1 (A) and FANCD2 foci (B) in T98G cells, T98G treated with the specific ATM inhibitor (ATMi) KU55933 at $10 \mu M$ or the ATR/ATM inhibitor caffeine at $1 \mathrm{mM}$, as well as in GM05849 AT cells and in ATR mutated FO2-98 hTERT cells. Foci counts in control samples were subtracted. Bars represent average induced foci per cell; error bars show SEM from 3-5 experiments.

Figure 5: Phospho-Chk1 foci induction in bystander T98G cells. (B) Bars represent average $p$-Chk1 foci per cell; error bars show SEM from 2 
experiments. (C) Western blot analysis of Chk1 phosphorylation and $\beta$-actin expression. Densitometric intensity profiles are shown for control (thin line), 5 Gyirradiated (dashed line) and bystander samples (thick line). Densitometry readings are quantified on a linear scale. (D) Fold change relative to unirradiated controls in pChk1 expression levels of irradiated and bystander samples following normalisation to $\beta$-actin levels. Error bars show the standard errors.

Figure 6: Clonogenic survival of directly irradiated $(A)$ and bystander T98G cells (B) treated with $0 \mathrm{nM}$ or $10 \mathrm{nM}$ of Chk1 inhibitor UCN-01; error bars show SEM from 2-4 experiments. 


\section{References}

[1] K.M. Prise, J.M. O'Sullivan, Radiation-induced bystander signalling in cancer therapy, Nat Rev Cancer 9 (2009) 351-360.

[2] C. Mothersill, C.B. Seymour, Radiation-induced bystander effects-implications for cancer, Nat Rev Cancer 4 (2004) 158-164.

[3] Z. Goldberg, B.E. Lehnert, Radiation-induced effects in unirradiated cells: a review and implications in cancer, Int J Oncol 21 (2002) 337-349.

[4] C. Shao, V. Stewart, M. Folkard, B.D. Michael, K.M. Prise, Nitric oxidemediated signaling in the bystander response of individually targeted glioma cells, Cancer Res 63 (2003) 8437-8442.

[5] C. Shao, F.M. Lyng, M. Folkard, K.M. Prise, Calcium fluxes modulate the radiatin-induced bystander responses in targeted glioma and fibroblast cells, Radiat Res 166 (2006) 479-487.

[6] C. Mothersill, R.J. Seymour, C.B. Seymour, Bystander effects in repairdeficient cell lines, Radiat Res 161 (2004) 256-263.

[7] O.V. Belyakov, M. Folkard, C. Mothersill, K.M. Prise, B.D. Michael, Bystander-induced apoptosis and premature differentiation in primary urothelial explants after charged particle microbeam irradiation, Radiat Prot Dosimetry 99 (2002) 249-251.

[8] F.M. Lyng, P. Maguire, N. Kilmurray, C. Mothersill, C. Shao, M. Folkard, K.M. Prise, Apoptosis is initiated in human keratinocytes exposed to signalling factors from microbeam irradiated cells, Int J Radiat Biol 82 (2006) 393-399.

[9] F.M. Lyng, C.B. Seymour, C. Mothersill, Initiation of apoptosis in cells exposed to medium from the progeny of irradiated cells: a possible mechanism for bystander-induced genomic instability?, Radiat Res 157 (2002) 365-370.

[10] M.V. Sokolov, L.B. Smilenov, E.J. Hall, I.G. Panyutin, W.M. Bonner, O.A. Sedelnikova, lonizing radiation induces DNA double-strand breaks in bystander primary human fibroblasts, Oncogene 24 (2005) 7257-7265. 
[11] S. Burdak-Rothkamm, S.C. Short, M. Folkard, K. Rothkamm, K.M. Prise, ATR-dependent radiation-induced gammaH2AX foci in bystander primary human astrocytes and glioma cells, Oncogene 26 (2007) 993-1002.

[12] W. Han, L. Wu, S. Chen, L. Bao, L. Zhang, E. Jiang, Y. Zhao, A. Xu, T.K. Hei, Z. Yu, Constitutive nitric oxide acting as a possible intercellular signaling molecule in the initiation of radiation-induced DNA double strand breaks in non-irradiated bystander cells, Oncogene (2006).

[13] H. Yang, N. Asaad, K.D. Held, Medium-mediated intercellular communication is involved in bystander responses of X-ray-irradiated normal human fibroblasts, Oncogene 24 (2005) 2096-2103.

[14] B. Hu, L. Wu, W. Han, L. Zhang, S. Chen, A. Xu, T.K. Hei, Z. Yu, The time and spatial effects of bystander response in mammalian cells induced by low dose radiation, Carcinogenesis 27 (2006) 245-251.

[15] E.P. Rogakou, D.R. Pilch, A.H. Orr, V.S. Ivanova, W.M. Bonner, DNA double-stranded breaks induce histone H2AX phosphorylation on serine 139, J Biol Chem 273 (1998) 5858-5868.

[16] S. Burdak-Rothkamm, K. Rothkamm, K.M. Prise, ATM acts downstream of ATR in the DNA damage response signaling of bystander cells, Cancer Res 68 (2008) 7059-7065.

[17] P.R. Andreassen, G.P. Ho, A.D. D'Andrea, DNA damage responses and their many interactions with the replication fork, Carcinogenesis 27 (2006) 883-892.

[18] R.D. Kennedy, A.D. D'Andrea, The Fanconi Anemia/BRCA pathway: new faces in the crowd, Genes Dev 19 (2005) 2925-2940.

[19] W. Wang, Emergence of a DNA-damage response network consisting of Fanconi anaemia and BRCA proteins, Nat Rev Genet 8 (2007) 735-748.

[20] A.R. Venkitaraman, Tracing the network connecting BRCA and Fanconi anaemia proteins, Nat Rev Cancer 4 (2004) 266-276.

[21] P.R. Andreassen, A.D. D'Andrea, T. Taniguchi, ATR couples FANCD2 monoubiquitination to the DNA-damage response, Genes Dev 18 (2004) 1958-1963. 
[22] M. Bogliolo, A. Lyakhovich, E. Callen, M. Castella, E. Cappelli, M.J. Ramirez, A. Creus, R. Marcos, R. Kalb, K. Neveling, D. Schindler, J. Surralles, Histone H2AX and Fanconi anemia FANCD2 function in the same pathway to maintain chromosome stability, Embo J 26 (2007) 13401351.

[23] X. Wang, R.D. Kennedy, K. Ray, P. Stuckert, T. Ellenberger, A.D. D'Andrea, Chk1-mediated phosphorylation of FANCE is required for the Fanconi anemia/BRCA pathway, Mol Cell Biol 27 (2007) 3098-3108.

[24] Q. Liu, S. Guntuku, X.S. Cui, S. Matsuoka, D. Cortez, K. Tamai, G. Luo, S. Carattini-Rivera, F. DeMayo, A. Bradley, L.A. Donehower, S.J. Elledge, Chk1 is an essential kinase that is regulated by Atr and required for the G(2)/M DNA damage checkpoint, Genes Dev 14 (2000) 1448-1459.

[25] Z. Xiao, Z. Chen, A.H. Gunasekera, T.J. Sowin, S.H. Rosenberg, S. Fesik, $\mathrm{H}$. Zhang, Chk1 mediates $\mathrm{S}$ and $\mathrm{G} 2$ arrests through Cdc25A degradation in response to DNA-damaging agents, J Biol Chem 278 (2003) 2176721773.

[26] R.D. Kennedy, A.D. D'Andrea, DNA repair pathways in clinical practice: lessons from pediatric cancer susceptibility syndromes, J Clin Oncol 24 (2006) 3799-3808.

[27] J.N. Sarkaria, E.C. Busby, R.S. Tibbetts, P. Roos, Y. Taya, L.M. Karnitz, R.T. Abraham, Inhibition of ATM and ATR kinase activities by the radiosensitizing agent, caffeine, Cancer Res 59 (1999) 4375-4382.

[28] P. Nghiem, P.K. Park, Y. Kim, C. Vaziri, S.L. Schreiber, ATR inhibition selectively sensitizes $\mathrm{G} 1$ checkpoint-deficient cells to lethal premature chromatin condensation, Proc. Natl. Acad. Sci. U.S.A. 98 (2001) 90929097.

[29] A. Soriani, A. Zingoni, C. Cerboni, M.L. lannitto, M.R. Ricciardi, V. Di Gialleonardo, M. Cippitelli, C. Fionda, M.T. Petrucci, A. Guarini, R. Foà, A. Santoni, ATM-ATR-dependent up-regulation of DNAM-1 and NKG2D ligands on multiple myeloma cells by therapeutic agents results in 
enhanced NK-cell susceptibility and is associated with a senescent phenotype, Blood 113 (2008) 3503-3511.

[30] E. Raderschall, E.I. Golub, T. Haaf, Nuclear foci of mammalian recombination proteins are located at single-stranded DNA regions formed after DNA damage, Proc. Natl. Acad. Sci. U.S.A. 96 (1999) 1921-1926.

[31] T.P. Heffernan, D.A. Simpson, A.R. Frank, A.N. Heinloth, R.S. Paules, M. Cordeiro-Stone, W.K. Kaufmann, An ATR- and Chk1-dependent S checkpoint inhibits replicon initiation following UVC-induced DNA damage, Mol Cell Biol 22 (2002) 8552-8561.

[32] V. Rodriguez-Bravo, S. Guaita-Esteruelas, R. Florensa, O. Bachs, N. Agell, Chk1- and Claspin-Dependent but ATR/ATM- and Rad17Independent DNA Replication Checkpoint Response in HeLa Cells, Cancer Res 66 (2006) 8672-8679.

[33] Manders EM, Stap J, Brakenhoff GJ, van Driel R, Aten JA, Dynamics of three-dimensional replication patterns during the S-phase, analysed by double labelling of DNA and confocal microscopy, J Cell Sci 103 (1992) 857-862.

[34] Costes SV, Daelemans D, Cho EH, Dobbin Z, Pavlakis G, LOckett, Automatic and quantitative measurement of protein-protein colocalization in live cells, Biophys J 86 (2004) 3993-4003.

[35] N.G. Howlett, T. Taniguchi, S.G. Durkin, A.D. D'Andrea, T.W. Glover, The Fanconi anemia pathway is required for the DNA replication stress response and for the regulation of common fragile site stability, Hum Mol Genet 14 (2005) 693-701.

[36] C.E. Redon, J.S. Dickey, A.J. Nakamura, I.G. Kareva, D. Naf, S. Nowsheen, T.B. Kryston, W.M. Bonner, A.G. Georgakilas, O.A. Sedelnikova, Tumors induce complex DNA damage in distant proliferative tissues in vivo, Proc Natl Acad Sci U S A 107 (2010) 17992-17997.

[37] S. Gaddameedhi, A. Sancar, Melanoma and DNA damage from a distance (farstander effect), Pigment Cell Melanoma Res 24 (2010) 3-20. 
[38] A. Facoetti, L. Mariotti, F. Ballarini, A. Bertolotti, R. Nano, F. Parsi, E. Ranza, A. Ottolenghi, Experimental and theoretical analysis of cytokine release for the study of radiation-induced bystander effect, Int J Radiat Biol. 85 (2009) 690-699.

[39] Y. Zhang, J. Zhou, J. Baldwin, K.D. Held, K.M. Prise, R. W. Redmond, H.L. Liber, lonizing radiation-induced bystander mutagenesis and adaptation: quantitative and temporal aspects, Mutat Res. 671(2009) 2025.

[40] H. Nagasawa, J.B. Little, Bystander effect for chromosomal aberrations induced in wild-type and repair deficient $\mathrm{CHO}$ cells by low fluences of alpha particles, Mutat Res 508 (2002) 121-129.

[41] F.M. Lyng, C.B. Seymour, C. Mothersill, Production of a signal by irradiated cells which leads to a response in unirradiated cells characteristic of initiation of apoptosis, Br. J. Cancer 83 (2000) 12231230.

[42] A. Rothfuss, M. Grompe, Repair kinetics of genomic interstrand DNA cross-links: evidence for DNA double-strand break-dependent activation of the Fanconi anemia/BRCA pathway, Mol Cell Biol 24 (2004) 123-134.

[43] J. Dunn, M. Potter, A. Rees, T.M. Runger, Activation of the Fanconi anemia/BRCA pathway and recombination repair in the cellular response to solar ultraviolet light, Cancer Res 66 (2006) 11140-11147.

[44] N. Spardy, A. Duensing, D. Charles, N. Haines, T. Nakahara, P.F. Lambert, S. Duensing, The human papillomavirus type 16 E7 oncoprotein activates the Fanconi anemia (FA) pathway and causes accelerated chromosomal instability in FA cells, J Virol 81 (2007) 13265-13270.

[45] H. Nagasawa, J.B. Little, Induction of sister chromatid exchanges by extremely low doses of alpha-particles, Cancer Res 52 (1992) 6394-6396.

[46] H. Nagasawa, P.F. Wilson, D.J. Chen, L.H. Thompson, J.S. Bedford, J.B. Little, Low doses of alpha particles do not induce sister chromatid exchanges in bystander Chinese hamster cells defective in homologous recombination, DNA Repair (Amst) 7 (2008) 515-522. 
[47] K. Neveling, R. Kalb, A.R. Florl, S. Herterich, R. Friedl, H. Hoehn, C. Hader, F.H. Hartmann, I. Nanda, C. Steinlein, M. Schmid, H. Tonnies, C.D. Hurst, M.A. Knowles, H. Hanenberg, W.A. Schulz, D. Schindler, Disruption of the FA/BRCA pathway in bladder cancer, Cytogenet Genome Res 118 (2007) 166-176.

[48] P. van der Groep, M. Hoelzel, H. Buerger, H. Joenje, J.P. de Winter, P.J. van Diest, Loss of expression of FANCD2 protein in sporadic and hereditary breast cancer, Breast Cancer Res Treat 107 (2008) 41-47.

[49] G. Narayan, H. Arias-Pulido, S.V. Nandula, K. Basso, D.D. Sugirtharaj, H. Vargas, M. Mansukhani, J. Villella, L. Meyer, A. Schneider, L. Gissmann, M. Durst, B. Pothuri, V.V. Murty, Promoter hypermethylation of FANCF: disruption of Fanconi Anemia-BRCA pathway in cervical cancer, Cancer Res 64 (2004) 2994-2997.

[50] H. Farmer, N. McCabe, C.J. Lord, A.N. Tutt, D.A. Johnson, T.B. Richardson, M. Santarosa, K.J. Dillon, I. Hickson, C. Knights, N.M. Martin, S.P. Jackson, G.C. Smith, A. Ashworth, Targeting the DNA repair defect in BRCA mutant cells as a therapeutic strategy, Nature 434 (2005) 917-921.

[51] S. Burdak-Rothkamm, K. Prise, New molecular targets in radiotherapy: DNA damage signalling and repair in targeted and non-targeted cells, Eur J Pharmacol 625 (2009) 151-155.

[52] E. Gluckman, A. Devergie, J. Dutreix, Radiosensitivity in Fanconi anaemia: application to the conditioning regimen for bone marrow transplantation, Br. J. Haematol. 54 (1983) 431-440.

[53] C.S. Djuzenova, A. Rothfuss, U. Oppitz, G. Spelt, D. Schindler, H. Hoehn, M. Flentje, Response to X-irradiation of Fanconi anemia homozygous and heterozygous cells assessed by the single-cell gel electrophoresis (comet) assay, Lab. Invest. 81 (2001) 185-192.

[54] B.P. Alter, Radiosensitivity in Fanconi's anemia patients, Radiother Oncol 62 (2002) 345-347. 
[55] C.S. Djuzenova, M. Flentje, Characterization of Fanconi anemia fibroblasts in terms of clonogenic survival and DNA damage assessed by the Comet assay, Med. Sci. Monit. 8 (2002) BR421-30.

[56] B.C. Godthelp, P.P.W. van Buul, N.G.J. Jaspers, E. ElghalbzouriMaghrani, A. van Duijn-Goedhart, F. Arwert, H. Joenje, M.Z. Zdzienicka, Cellular characterization of cells from the Fanconi anemia complementation group, FA-D1/BRCA2, Mutat. Res. 601 (2006) 191-201.

[57] A. Mohseni-Meybodi, H. Mozdarani, S. Mozdarani, DNA damage and repair of leukocytes from Fanconi anaemia patients, carriers and healthy individuals as measured by the alkaline comet assay, Mutagenesis 24 (2009) 67-73.

[58] A.D. D'Andrea, Susceptibility pathways in Fanconi's anemia and breast cancer, N. Engl. J. Med. 362 (2010) 1909-1919.

[59] A.C. Birkeland, A.D. Auerbach, E. Sanborn, B. Parashar, W.I. Kuhel, S.C. Chandrasekharappa, A. Smogorzewska, D.I. Kutler, Postoperative clinical radiosensitivity in patients with fanconi anemia and head and neck squamous cell carcinoma, Arch. Otolaryngol. Head Neck Surg. 137 (2011) 930-934. 

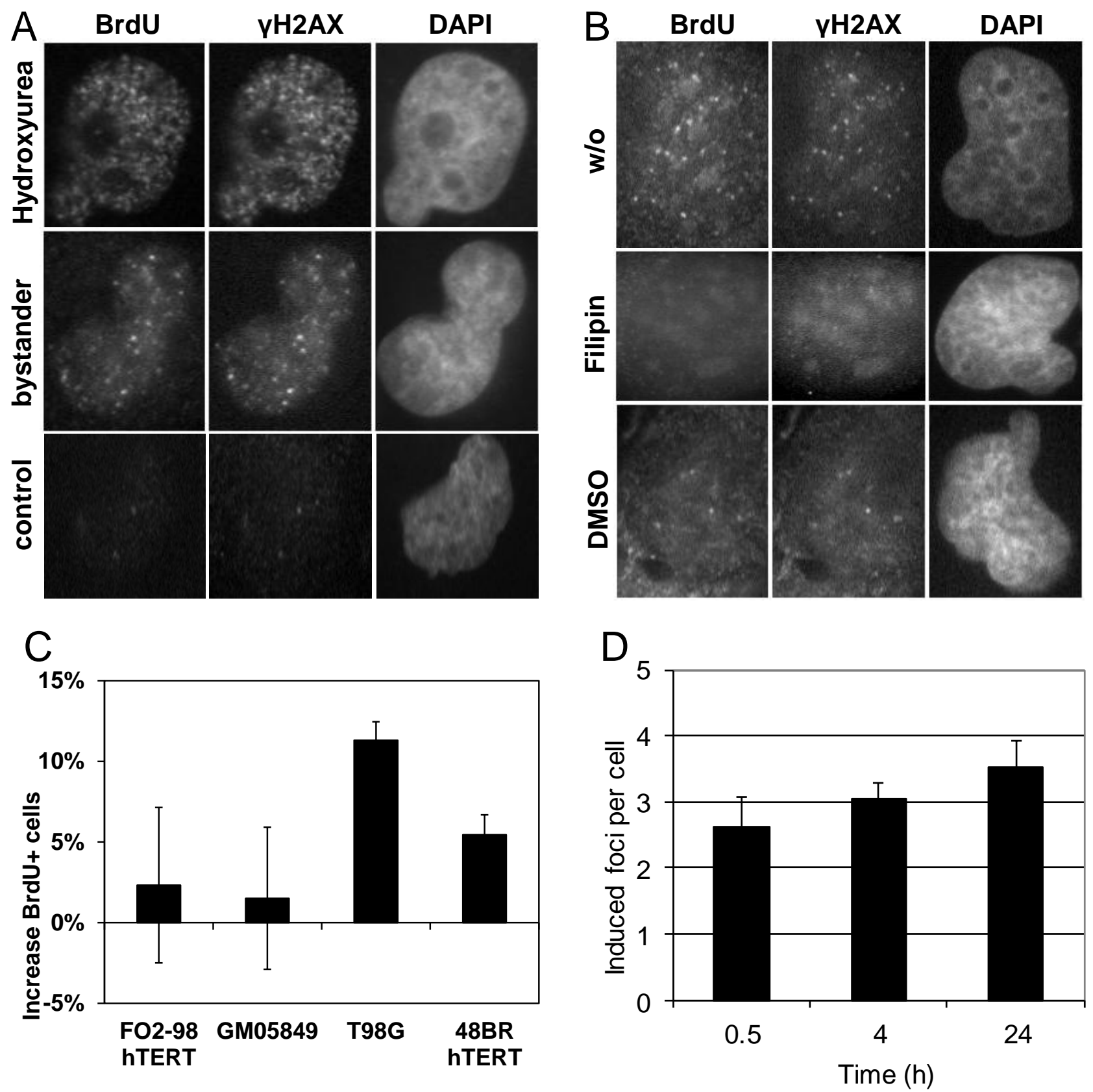


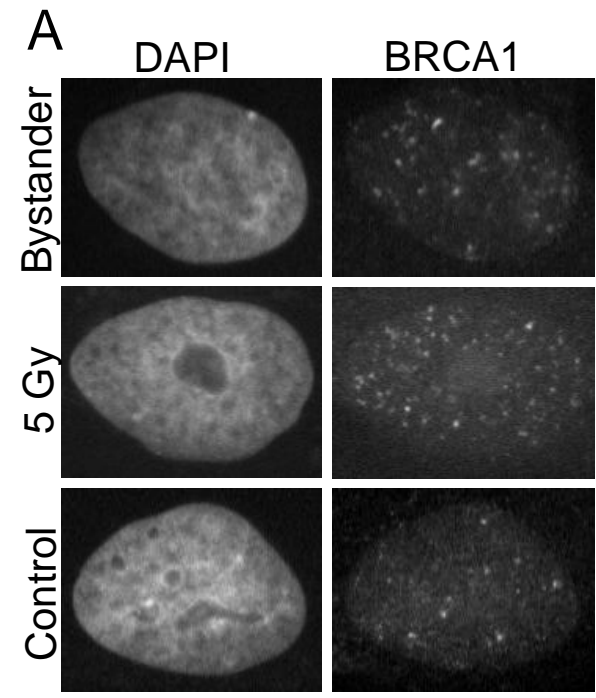

D $\quad 30 \mathrm{~min}$
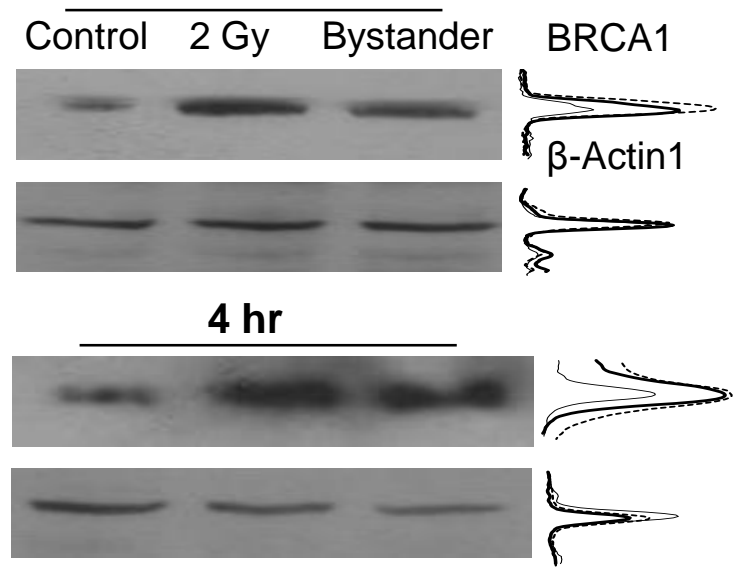
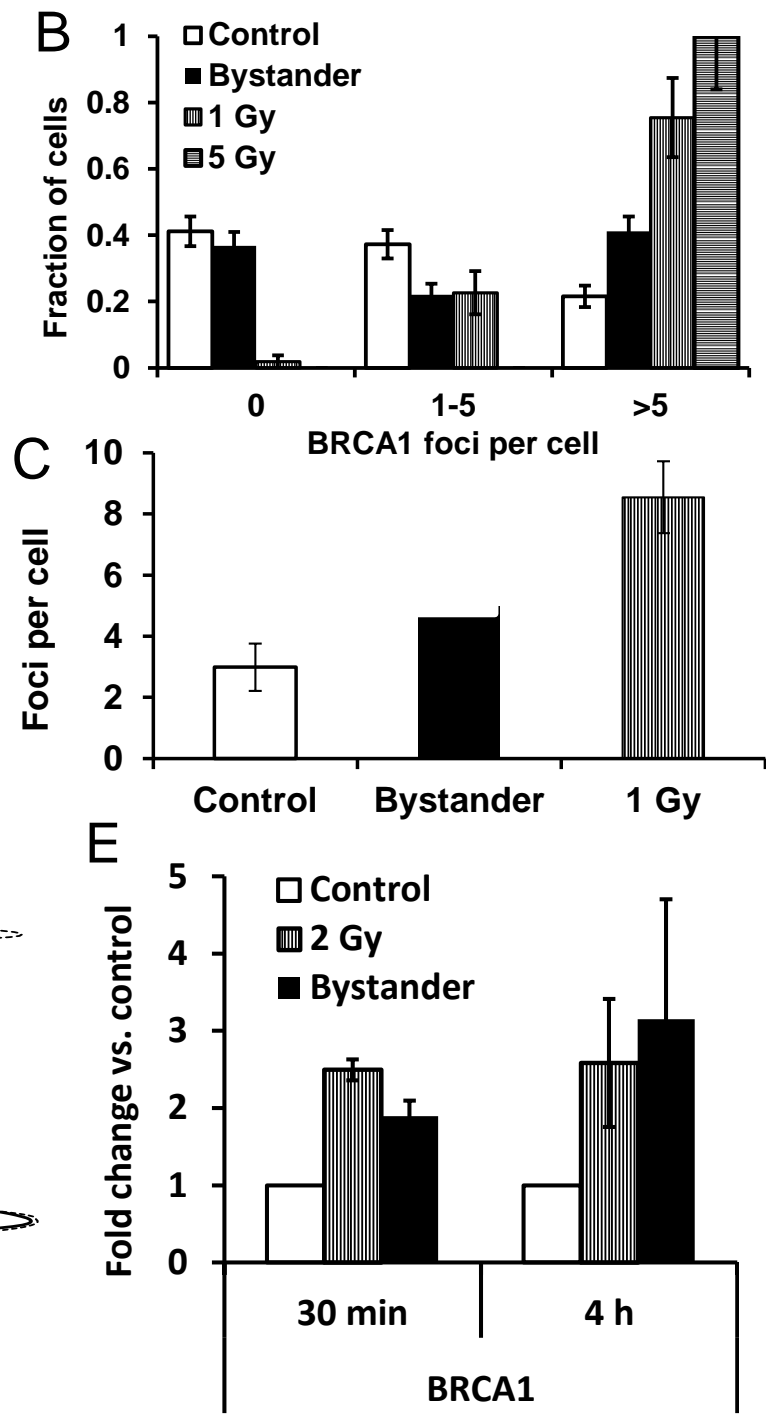

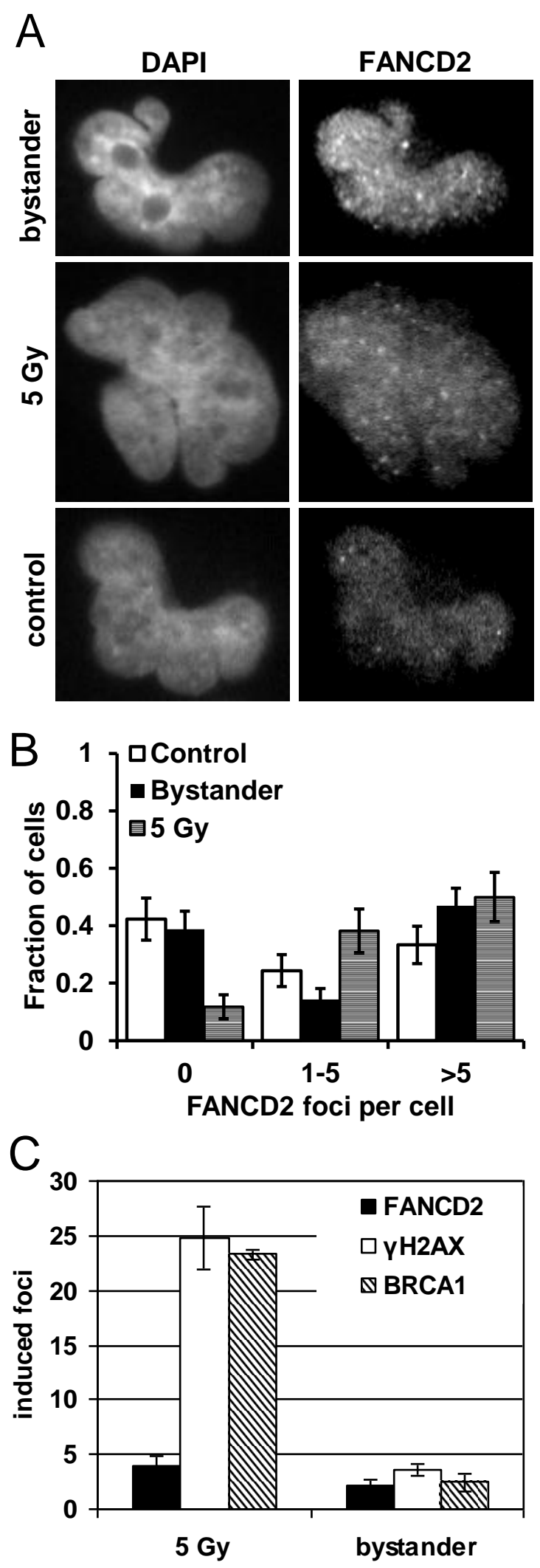


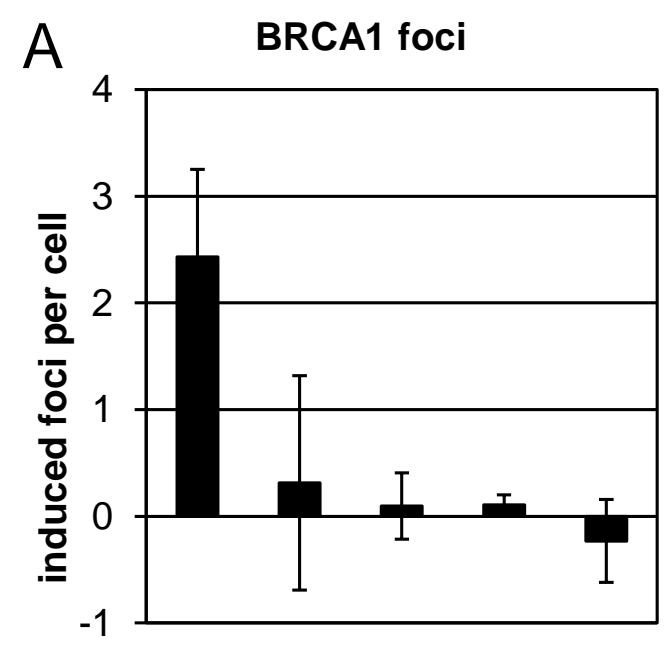

B FANCD2 foci

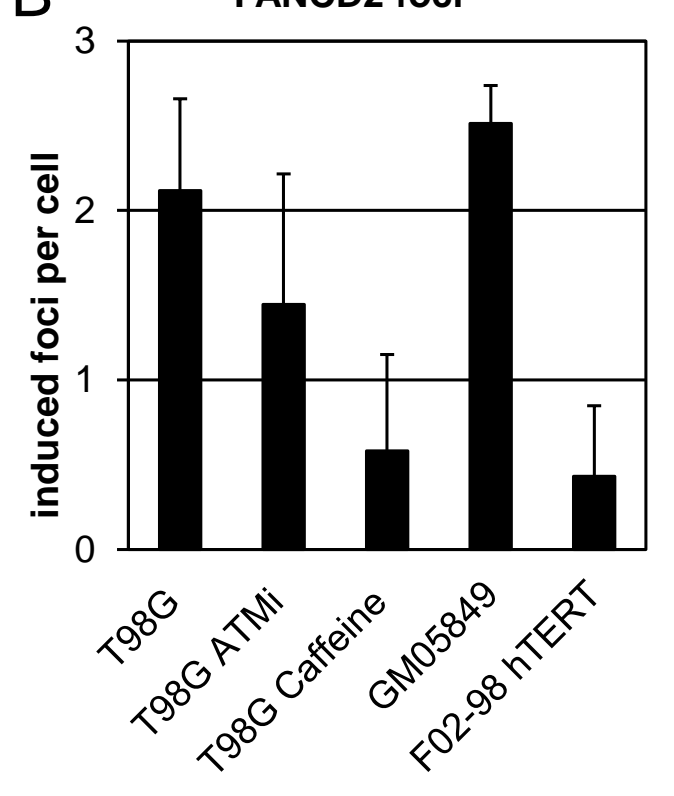

Figure 4 

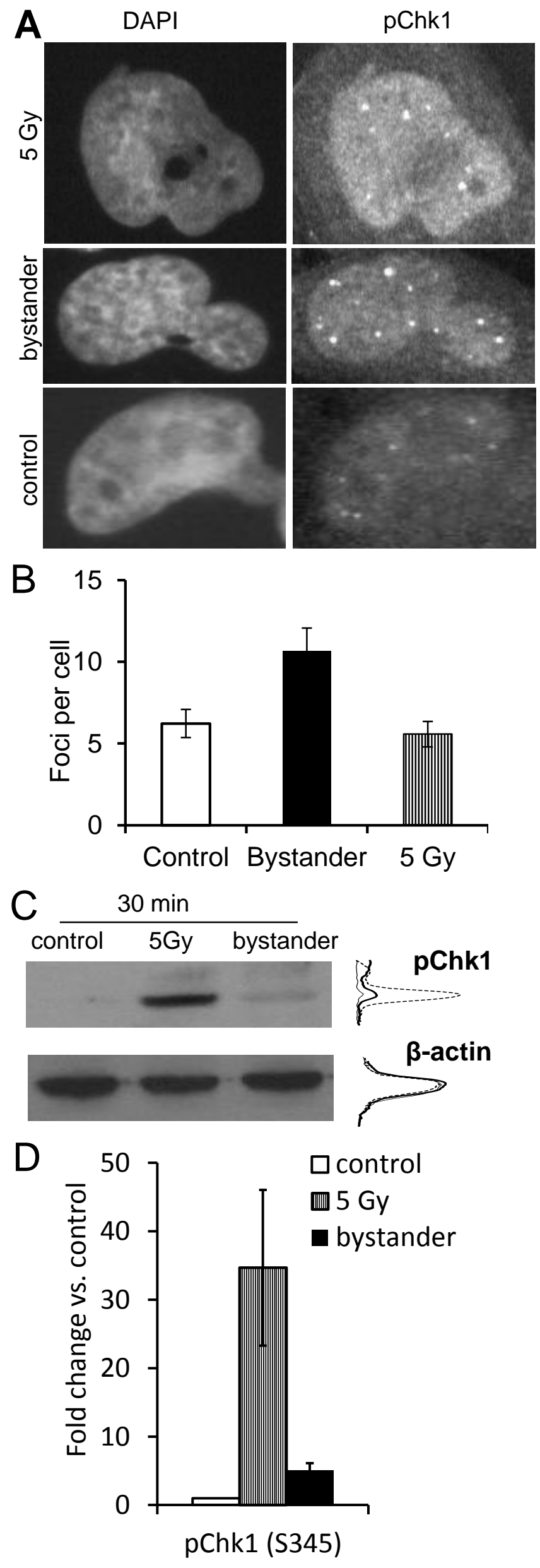
A

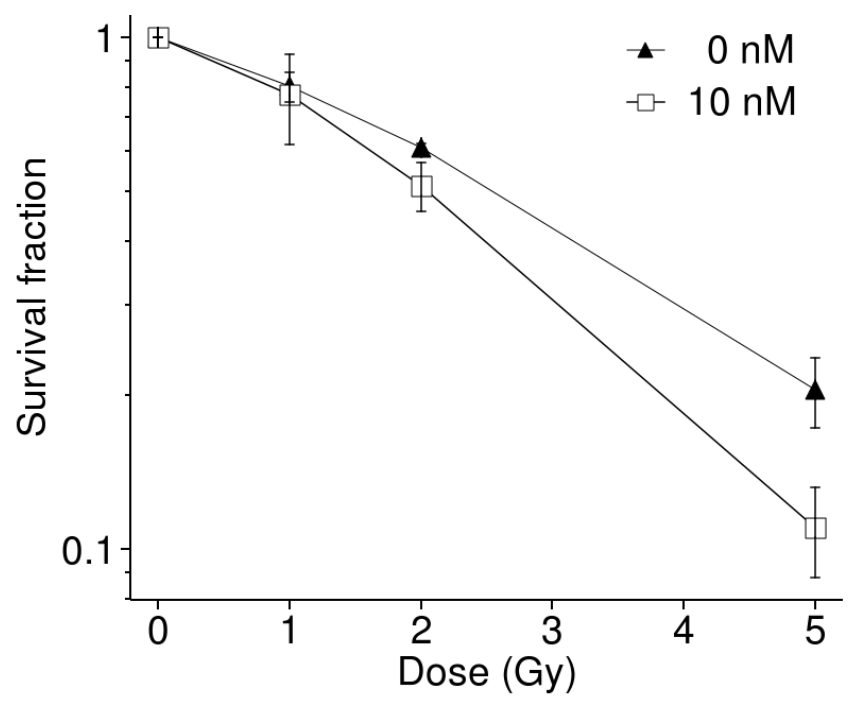

B

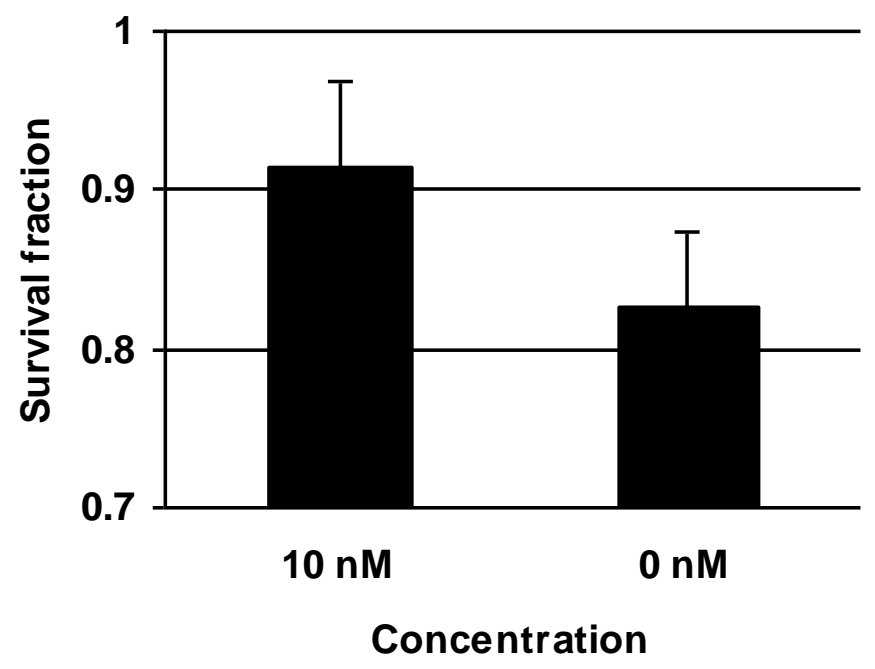




\section{Controls, DMSO-treated}

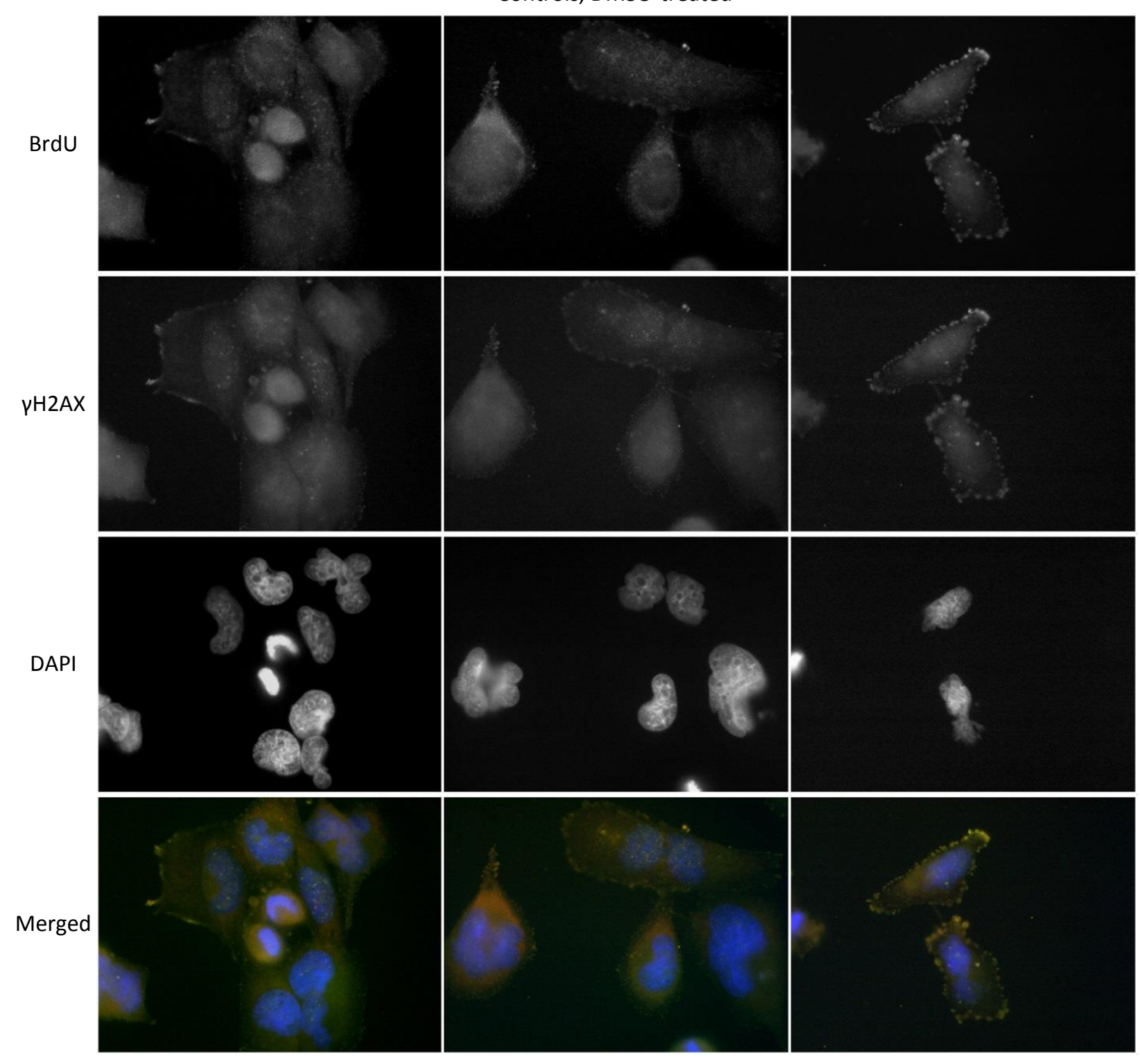

Figure S1E. Immunofluorescence microscopy of BrdU foci (red) and $\mathrm{yH} 2 \mathrm{AX}$ foci (green) at sites of stalled replication in DMSO-treated control cells. Samples were counter-stained with DAPI (blue). See Figure 1B for details. Each image is $162 \mu \mathrm{m}$ wide. 


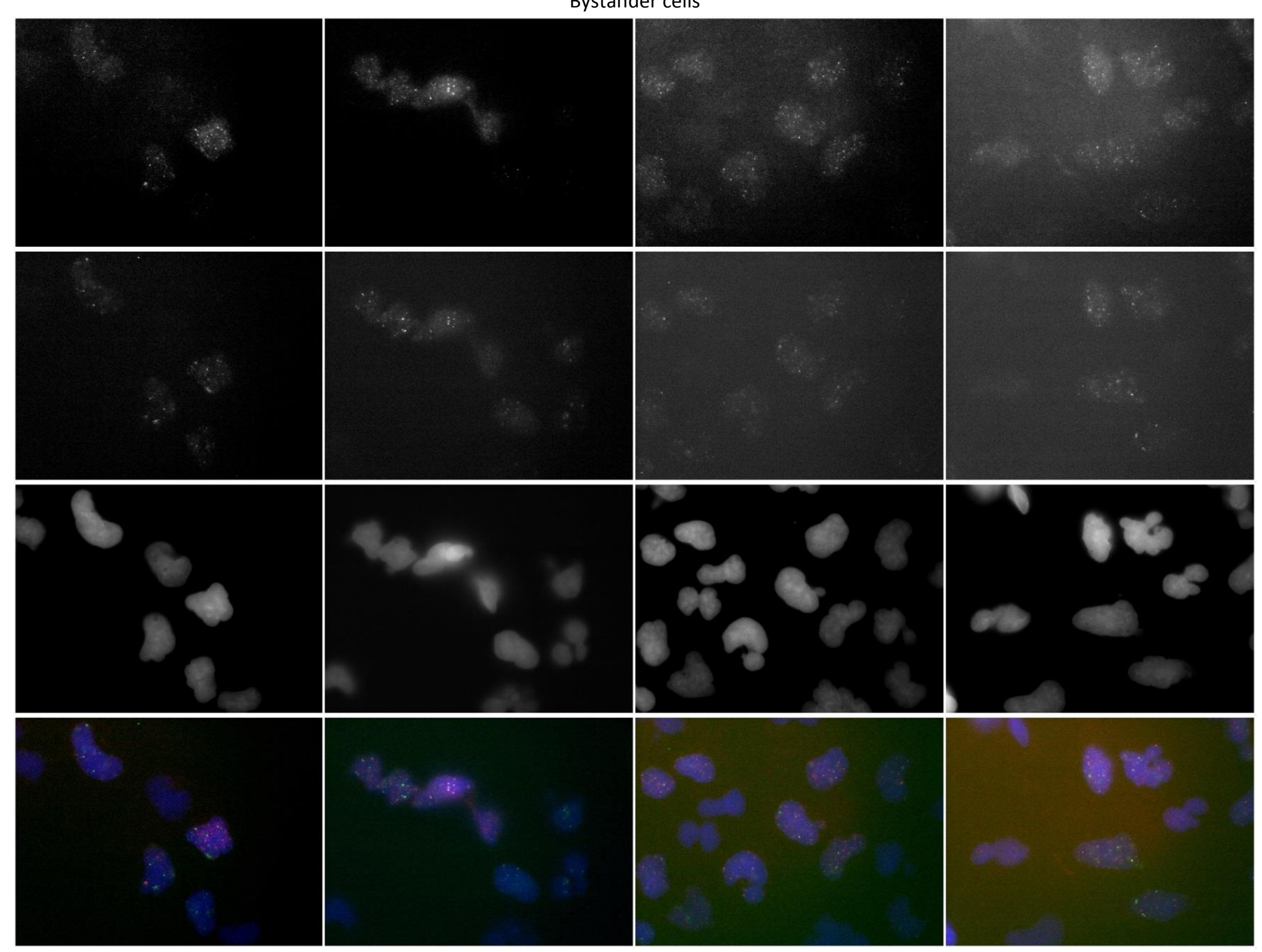

Figure S2A, cont'd. Co-immunofluorescence microscopy of FANCD2 foci (red) and BRCA1 foci (green) at sites of stalled replication in bystander cells. Samples were counterstained with DAPI (blue). See Figures $2 \mathrm{~A}$ and $3 \mathrm{~A}$ for details. Each image is $97 \mu \mathrm{m}$ wide. 
Bystander cells

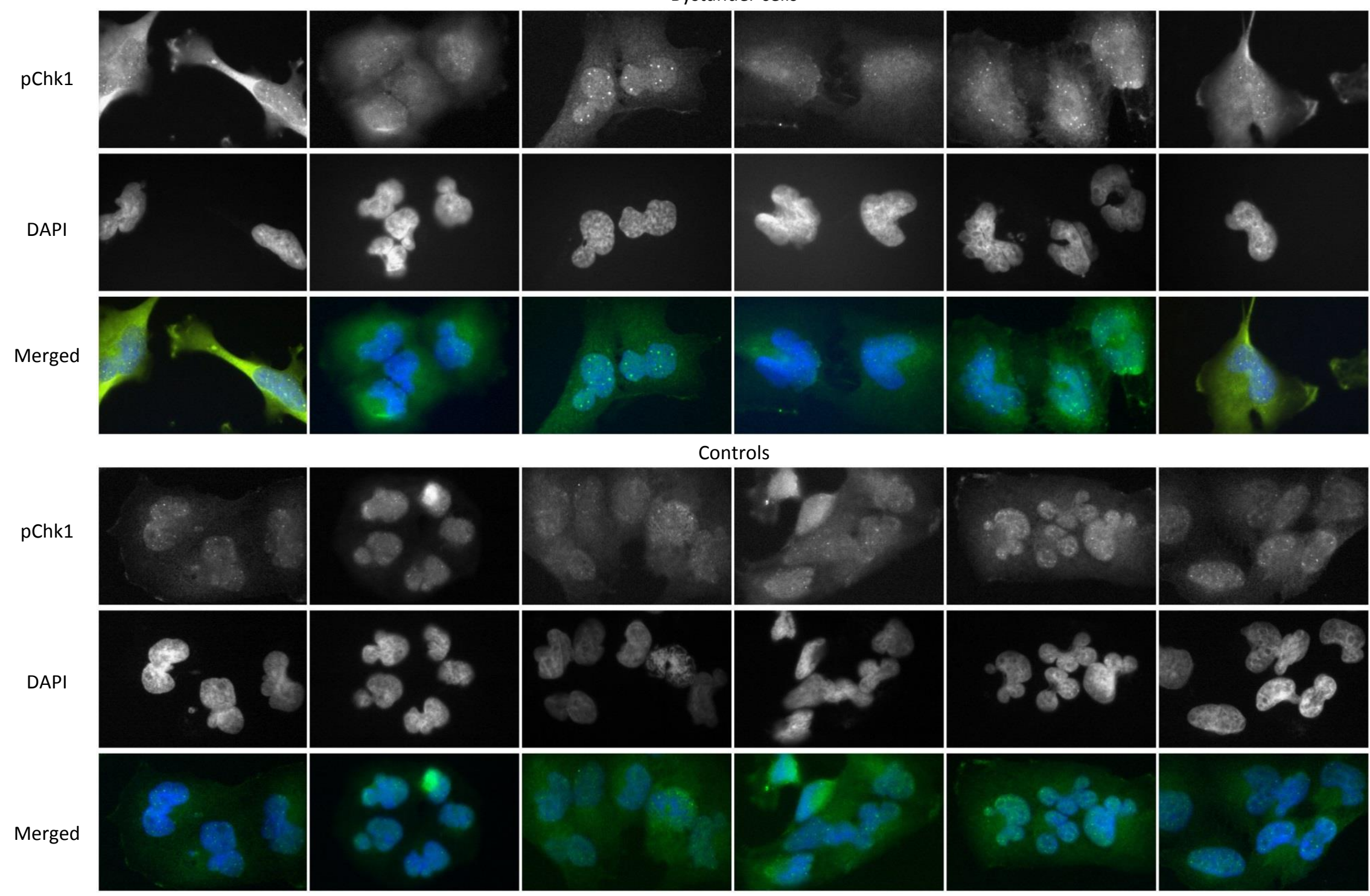

Figure S3. Immunofluorescence microscopy of pChk1 foci (green) in bystander cells. Samples were counter-stained with DAPI (blue). See Figure 5A for details. Each image is $57 \mu \mathrm{m}$ wide. 
FANCD2

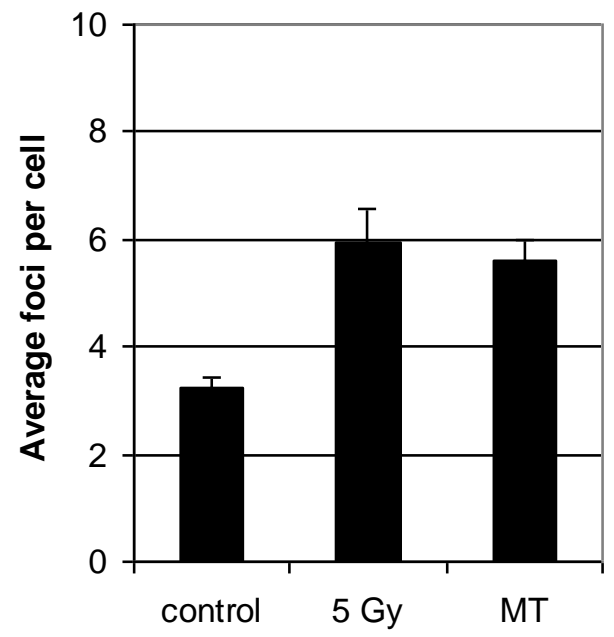

gamma-H2AX

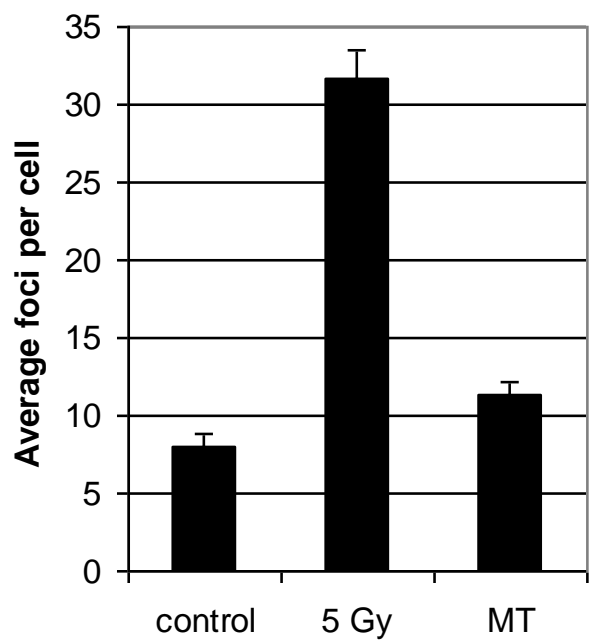

p-Chk1

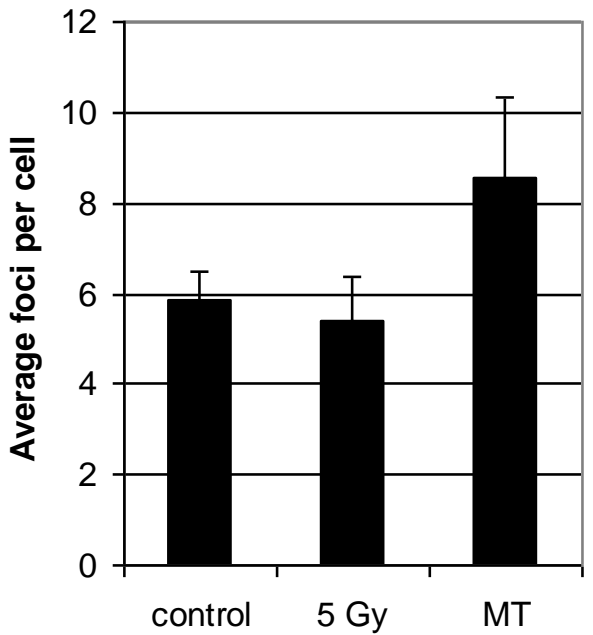

BRCA1

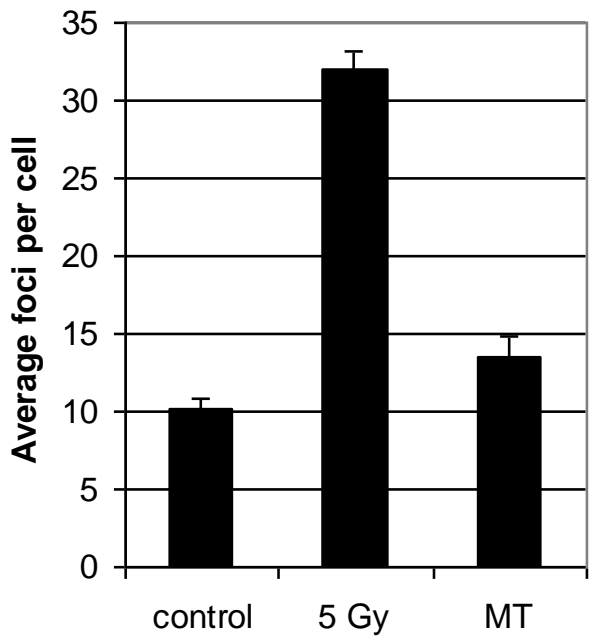

Figure S4. Average number of p-Chk1, FANCD2, BRCA1 and gamma-H2AX foci per T98G cell in foci-bearing cells only in control, 5 Gy-irradiated and bystander cell cultures treated with medium from 2 Gy-irradiated cells. Foci data were collected from a total of 348 control, 333 bystander cells and 305 directly irradiated cells in two experiments. The analysis includes foci bearing cells only. Error bars show the standard errors. 
Bystander cells

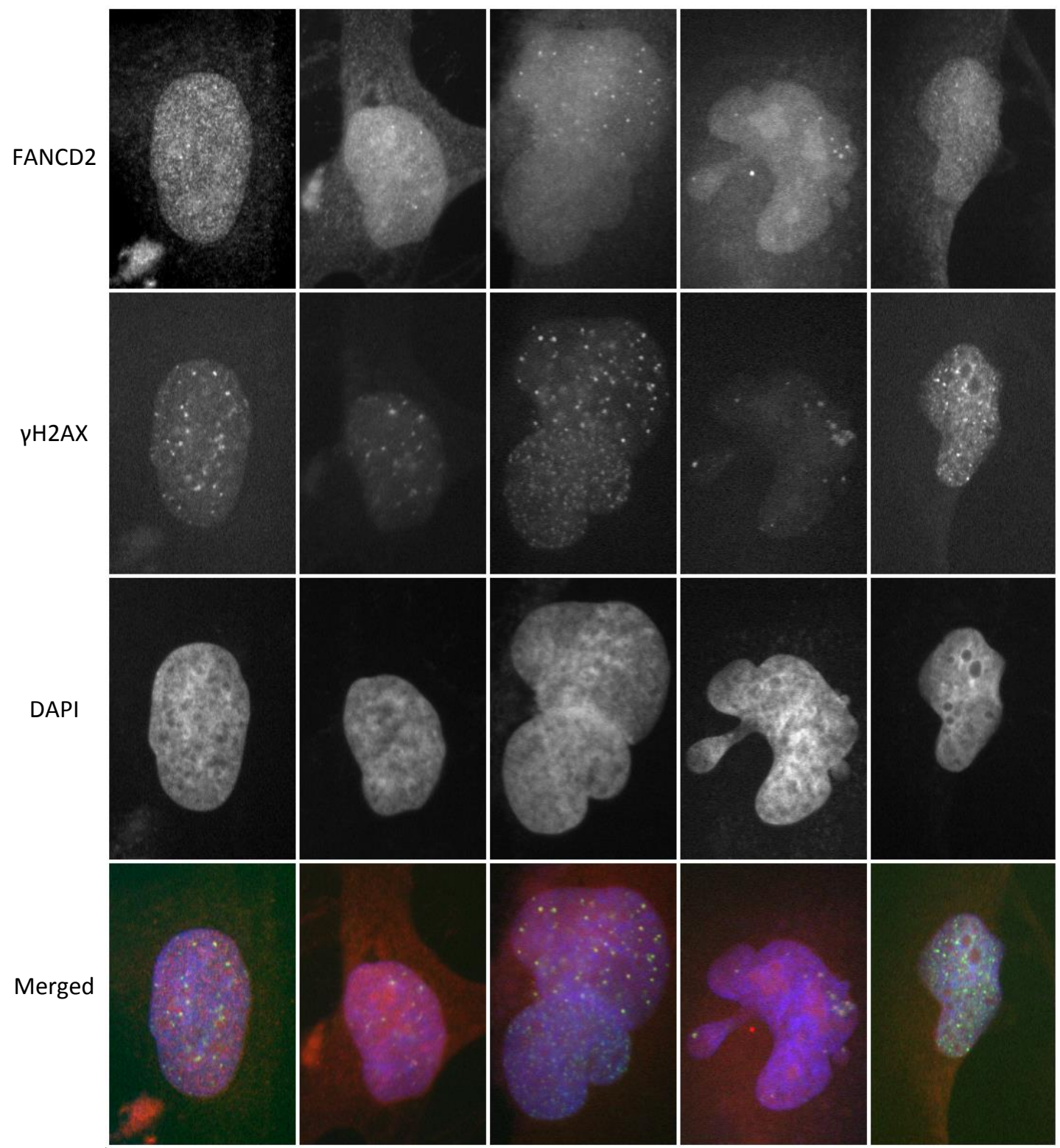

Figure S5. Immunofluorescence microscopy of FANCD2 foci (red) and $\mathrm{yH} 2 \mathrm{AX}$ foci (green) in bystander cells. Samples were counter-stained with DAPI (blue). 